\title{
INTERPRETATIONS
}

Article received on $17^{\text {th }}$ February 2015

Article accepted on $25^{\text {th }}$ March 2015

UDC: $316.75: 78(497.1)$

$316.72: 316.75(497.1)$

321.728/.74:929 Тито

\section{Rade Pantic**}

Singidunum University, Belgrade

Faculty of Media and Communications

\section{“THE HERO'S VOICE LET US FOLLOW, MAY TITO LEAD US": AN INTERPRETATION OF THE PHENOMENON OF SONGS ABOUT TITO BASED ON THE THEORY OF IDEOLOGICAL INTERPELLATION}

\begin{abstract}
This article offers an interpretation of songs about Josip Broz Tito based on the theory of the ideological interpellation of individuals into subjects, which was first formulated by Louis Althusser and then expanded by Rastko Močnik. The first part of the essay is a brief summary of Althusser's and Močnik's respective theories of ideology, ideological interpellation, and the participation of ideological mechanisms of identification in the processes of the reproduction of social systems and class domination. These theories are then applied to songs about Tito as a case study, attempting to explain the mechanisms whereby these songs produced the "Tito effect" as an instance of identifying with "the subject supposed to know", which interpellated the subjects of socialist Yugoslavia. Two cycles of songs about Tito are singled out, in an attempt to reveal the different modes whereby they produced the effect of ideological interpellation and simultaneously trace the effects of these interpellation processes in the mechanisms of reproducing the Yugoslav state at two
\end{abstract}

* Author contact information: rade.pantic@fmk.edu.rs 
different historical junctures. Finally, using the concept of "the subject supposed to believe", I will try to explain the popularity of these songs today and the mechanisms of identifying with them at a time when they no longer produce the effect of domination.

Keywords: Louis Althusser, Rastko Močnik, Josip Broz Tito, ideology, ideological interpellation, identification, Yugoslavia, Marxism, psychoanalysis

In this paper, I will try to approach the phenomenon of songs about Tito by way of the theory of the ideological interpellation of individuals into subjects, formulated by the French Marxist philosopher Louis Althusser and expanded by the Slovenian sociologist and theorist Rastko Močnik. This theoretical platform seems able to make a significant contribution to the problematic of the ideological identification and subjection of individuals through music and expand it with questions about the participation of musical works in ideological and social processes of the reproduction of certain political systems. ${ }^{1}$ Therefore, it might be interesting to approach the problematic of songs about Tito with the Althusserian Marxist-psychoanalytic theoretical apparatus and thereby determine the identification mechanisms that these songs helped to set up, as well as the role of those mechanisms in the reproduction of the social system of the Socialist Federal Republic of Yugoslavia (SFRY). In the first part of the essay, I offer a brief explication of the premises underlying Althusser's theory of ideological interpellation and Močnik's revision and expansion of that theory, and then apply that theoretical apparatus on the ideological mechanisms of socialist Yugoslavia, as a case study, and the role that Tito's cult played in these mechanisms, with special focus on the ideological-identification function of songs about Tito. Močnik's elaboration of Althusser's theory by way of introducing the concepts of "the subject supposed to know" and "the subject supposed to believe" as instances of identification seems especially apt to explain the identificatory processes in these songs, as well as to contribute to a better understanding of more general theoretical problems of identification through musical works and the relationship between music and ideological processes.

\section{Althusser's Theory of the Ideological Interpellation of Individuals into Subjects}

In his famous essay "Ideology and Ideological State Apparatuses", the French Marxist philosopher Louis Althusser performed an epistemological

\footnotetext{
${ }^{1}$ An initial version of this theory was given by Miško Šuvaković; see Miško Šuvaković, "Muzika i ideologija", in: Paragrami tela/figure. Predavanja i rasprave o strategijama i taktikama teorijskog izvođenja u modernom i postmodernom performance art-u, teatru, operi, muzici, filmu i tehnoumetnosti, Belgrade, Centar za novo pozorište i igru, 2001, 272-281.
} 
Pantic, R.: “The hero's voice let us follow, may Tito lead us"...

break in the field of ideology theory. He wrested the concept of ideology away from the problematic of social consciousness, including the traditional Marxist concept of ideology as false consciousness, and attempted to offer a theory of ideology's materialist grounding. In his essay, Althusser made two key claims, with which he sought to ground his theory of ideology: "ideology interpellates individuals as subjects" ${ }^{2}$ and "ideology has a material existence". ${ }^{3}$ With the first claim, Althusser defined ideology as a specific discourse, with mechanisms of its own, whereby it interpellates individuals and produces their subject positions. Ideological discourse and its mechanism of subjection are based on the structure of specular centring: the subject effect is produced by doubling the produced subject with the producing Subject, to whom the produced subject is subjected. Ideology produces the subject effect by means of its specular structure, which produces in the individual the imaginary effect of misrecognition through and in the Other, whereby s/he becomes an ideological subject. The function of the Subject is precisely to provide a centre to the ideological discourse and to supply individuals, through that centre as a mirror image, with a point of identification and thus become their quasi-cause. Althusser explains the functioning of the specific discursive structure of ideology in the process of ideological interpellation by invoking the example of Christian religious ideology. A prerequisite of religious ideological interpellation is the construction of a Unique, Absolute, Other Subject - God, who addresses the human individual, lending her an identity wherein she recognizes herself and becomes a subject. In the very act of being addressed, the individual recognizes it is she who is being addressed and assumes the identity assigned to her by the Subject. The interpellated person turns around and recognizes that the address was indeed made to her and that she was the one who was addressed, and thereby becomes an ideological subject. The entire structure of ideology is thus centred in the image of the Absolute Subject; simultaneously, it ensures the following:

1) the interpellation of 'individuals' as subjects; 2) their subjection to the Subject; 3) the mutual recognition of subjects and Subject, the subjects' recognition of each other, and finally the subject's recognition of himself; 4) the absolute guarantee that everything really is so, and that on condition that the subjects recognize what they are and behave accordingly, everything will be all right: Amen - 'So be it'. ${ }^{4}$

The result of submitting to this scheme of ideological interprellation is such that individuals qua interpellated ideological subjects "act all by themselves".

\footnotetext{
2 Ibid., 261.

${ }^{3}$ Ibid., 258.

${ }^{4}$ Ibid., 268.
} 
The individual is thus subjected as a "free" subject who ostensibly acts in line with his own free beliefs; therefore, he, by his own "free will", takes part in the practices and rituals of religious apparatuses. According to Althusser, ideology exists only through the subject and for subjects, and the subject exists only through ideology and for ideology. The mechanism itself whereby ideology interpellates individuals into subjects is an unconscious mechanism. In Althusser's view, this is also the root of the ambiguity of subject as a term, which signifies both free subjectivity as a centre of initiative that initiates and accounts for its acts, as well as a subjected, enslaved being, deprived of all freedom, save the freedom to freely choose her own subjection.

The concept of ideological state apparatuses establishes a link between the ideological interpellation claim and that of the material existence of ideology. Althusser argues for his thesis that ideology has a material existence by pointing out that ideology is realized through practices that are located within ideological state apparatuses. According to his claim, what drives an individual's acts are not her conscious ideas, but material practices and rituals inscribed in ideological state apparatuses, in which those acts are embedded. Therefore, not only does ideology lend meaning and identity to an individual by interpellating him into ideology and constituting him as a subject, but also, through the rituals and practices of ideological state apparatuses, it drives its operation in practical terms. Since they are realized through ideological practices within those apparatuses, the imaginary relations of individuals thus possess a material existence, which is manifested in their behaviours, actions, and deeds. Althusser summarizes these two claims by arguing that "ideology represents the imaginary relationship of individuals to their real conditions of existence". ${ }^{5}$ As the unconscious discourse of interpellation, ideology organizes the practical relations of individuals that are imaginary regarding their actual relations, determined by their positioning in the economic relations of production and the reproduction process of a given mode of the production of society, that is, the domination of a given class. Therefore, the real function of ideology and ideological subjects is the reproduction of capitalist relations of production, which also reproduces the class hegemony of the bourgeoisie.

\section{Močnik's Revision of Althusser's Theory}

The Slovenian theorist Rastko Močnik performed a critique and elaboration of Althusser's theory of ideological interpellation. Močnik's revision adds flexibility and complexity to Althusser's otherwise "rigid" and somewhat simplis-

\footnotetext{
${ }^{5}$ Ibid., 256.
} 
Pantic, R.: “The hero's voice let us follow, may Tito lead us”...

tic theory by introducing the distinction between the imaginary and symbolic domain of subjection and, by extension, the distinction between the identification instances of "the subject supposed to believe" and "the subject supposed to know". Močnik thus distinguishes between conditional imaginary identifications and unconditional symbolic interpellative identifications, which will, as we shall see, help us to explain the popularity of songs about Tito today, when Tito no longer represents an instance of interpellation that would manifest the ruling ideology of society and domination effect. Namely, Althusser's theory of ideological interpellation assumes the existence of only one ideological programme that subjects all individuals and for that reason, in Močnik's view, it cannot explain the existence of multiple ideological programmes in a single society, nor can it theorize the way the subjects of these differing ideologies communicate, which is a necessary condition for a society to function and reproduce itself at all. Močnik therefore asks: how is communication at all possible between members of one and the same society who are bound to different ideological programmes?

In Močnik's view, Althusser's concept of ideological interpellation was meant to bridge the gap in his theory between the way ideology functions in the social processes of the reproduction of the relations of production and the viewpoint of an individual subject, that is, her/his own perception of her/his place in the relations of production as a factor of production. Močnik argues that the function of Althusser's concept of interpellation was to compensate for the absence of this "subjective" dimension in his theory of ideology. In Močnik's view, one may retrieve this missing dimension in Althuser's theory of ideology by articulating Jacques Lacan's psychoanalytic theory with the Marxist theory of historical materialism. Močnik views the process of ideological interpellation as a process of subjection that comprises two interdependent mechanisms: the domain of subjection as a purely formal symbolic mechanism and that of identification as an imaginary relation that concerns the "content" of ideology. ${ }^{6}$ Ideological interpellation operates by setting up a relation of identification, but its success depends on its capacity to "trigger" the mechanism of subjection.

Močnik introduces the concept of "the subject supposed to believe" by positing his theory of ideology as one of interpretation. ${ }^{7}$ According to this theory, utterances are understood by means of possible background beliefs that lend

${ }^{6}$ Rastko Močnik, "Ideological Interpellation: Identification and Subjectivation", in: Katja Diefenbach et al. (eds.), Encountering Althusser: Politics and Materialism in Contemporary Radical Thought, New York/London, Bloomsbury Academic, 2013, 307-322.

${ }^{7}$ Rastko Močnik, "O ideologiji”, in Tri teorije: ideologija, nacija, institucija, Belgrade, Centar za savremenu umetnost, 2003, 3-76. 
them meaning. Interpretation thus proceeds not on a speech-reality axis, but in the dimension of utterance and its ideological background beliefs. Seeking to interpret a given utterance, the interpreting subject thus attempts to occupy a viewpoint wherefrom the utterance may be understood. Močnik calls this structural position, which is found in every discourse, "the subject supposed to believe". Therefore, the interpreting subject identifies with the instance of "the subject supposed to believe", with a subject position whereby s/he comes to believe that the utterance may be meaningful. However, this is a conditional identification, believing through another, through a mediator who represents a sort of "ideal interpellatee", who unconditionally and necessarily believes what $\mathrm{s} /$ he needs to believe in order to make the utterance meaningful. While imaginary identifications are conditional identifications with "the subject supposed to believe", that is, with possible beliefs, symbolic identification entails a necessary and unconditional identification, in which the subject "truly" believes. Moreover, this necessary identification, which constitutes interpellation, conditions the possibility of the subject's switching from one background belief to another. Therefore, the subject may "inhabit" several ideologies that simultaneously co-exist within a given society, provided that there be one in which s/he is interpellated. The subject's interpellation into a given ideology may succeed only if that ideology's background belief stimulates and captures the subject's unconscious desire. The subject is thus interpellated on an unconscious, phantasmatic level, which makes his identification with the background belief that interpellated him seem natural, necessary, and self-evident. ${ }^{8}$ Here, at a certain point, the demand for meaning stimulates an unconscious desire, which leads toward identifying with "the subject supposed to believe" and returns to the subject not only as meaning, but also as identification, whereby this subject, through whom identification occurs, is retroactively marked not only as a believing subject, but also as a subject of knowledge. ${ }^{9}$

In modern, "individualist" bourgeois societies, the role of the subject supposed to know is played by the nation, as the zero-degree institution of a given society. ${ }^{10}$ In modern societies, which exhibit multiple ideological conceptual schemes whereby different communities organize their social life, the function

\footnotetext{
${ }^{8}$ Rastko Močnik, "Ideology and Fantasy”, in: E. Ann Kaplan and Michael Sprinker (eds.), The Althusserian Legacy, London/New York, Verso, 1993, 139-156.

${ }^{9}$ Močnik borrowed the concept of "the subject supposed to know" from Jacques Lacan's psychoanalytic theory. See Jacques Lacan, The Seminar of Jacques Lacan, Book XI: Four Fundamental Concepts of Psychoanalysis, New York, W.W. Norton \& Company, 1977.

${ }^{10}$ Rastko Močnik, “O naciji”, in: Tri Teorije: Ideologija, nacija, institucija, Belgrade, Centar za savremenu umetnost, 2003, 79-127.
} 
Pantic, R.: “The hero's voice let us follow, may Tito lead us"...

of the nation is to supply a neutral conceptual scheme to represent their common position of utterance. Whereas other institutions of a society perform certain functions, the nation, as its zero-degree institution, has the sole function of securing the prerequisites for the existence of a given society as a whole. The instance of the nation as "the subject supposed to know" thus produces an empty assumption of knowledge that ensures the possibility of the existence of society as a whole, as well as the possibility of different modes of its existence. This necessary identification with "the subject supposed to know" is thus preliminary to any conditional identification with "the subject supposed to believe", which is ascribed to various ideological schemes that represent different possibilities of organizing a society. Therefore, this subject enables communication among members of society who inhabit different conceptual ideological schemes. The nation is thus a supplementary institution that solves the problem of communication in modern societies by interpellating subjects who belong to different ideological horizons and thus supplying them with a common point of identification, which enables mutual communication.

The nation unifies the social field into an internally inclusive and externally exclusive whole, by means of totalizing the society from within and delimiting it from without, that is, from other nations. A nation is thus defined by its relationship with other nations and in relation to the individuals it encompasses within its own limits. Precisely on account of this inclusivity, a nation is inherently defined not by its institutions, but in a direct relation to the individuals it holds together and provides with a common position of utterance. The result of this function of the nation is that an individual belongs to the nation directly, regardless of her/his status or belonging to any other institution. Ethnic identity is thus unconditional and the individual therefore accepts it as something intrinsic and self-evident. However, this automatic knowledge of one's ethnic identity is a formal knowledge bereft of any semantic content and therefore must be complemented with a particular ideology to provide it with ideological "content". The ideology that manages to over-determine the institution of the nation becomes the hegemonic, ruling ideology, which via "the subject supposed to know" interpellates subjects who identify with a given nation. The nation as the zero-degree institution thus produces the effect of a social whole only indirectly, via different ideologies, of which only one constitutes the hegemonic ideology. In nationally constituted communities, ideological struggle is waged precisely for the position of the ideology that will come to dominate the nation as its zero-degree institution.

Močnik then turns to his claim that every society is structurally not-whole, that is, shot through with antagonisms and contradictions that it cannot resolve. As the zero-degree institution, the nation then constitutes the supplementary instance that enables a society to function, by producing the effect of society as 
a whole. Namely, in Močnik's view, the "normal" operation of different social institutions and the legal and custom norms that they prescribe cause "abnormalities" that then must be removed by introducing additional or supplementary institutions. Močnik maintains that the ruling institution's interpellative power lies in its supplementary nature. Since there is always a gap between the demands of the social institutional norm and institutional practice itself, subjects must supplement it with another institution to interpellate them. Individuals are thus forced to reproduce this supplementary institutional process. Precisely the respect of institutional norms brings individuals into contradictions that confront them with mutually exclusive demands, which force them to look for supplementary solutions. Individuals are thus forced both to supplement social norms and, at the same time, fearing exclusion from the community on account of breaking its norms, to justify their supplementary choices. Precisely in this way they reproduce the social structure, which, as not-whole, requires supplementation. In Močnik's view, it is this paradox that enables social cohesion: "that which seems like a 'short circuit' in a given institution and that from the viewpoint of an individual manifests itself as a contradictory institutional demand is in fact the mechanism whereby an institution binds the individuals who "belong' to it". ${ }^{11}$

Namely, these contradictory institutional demands force individuals to leave decision-making to the ruling institution, "the subject supposed to know". In Močnik's view, the mechanism of ideological interpellation puts the individual in the position of the Lacanian vel, which forces him to make the only choice possible: to relinquish choosing to the other, that is, to the authority, which is precisely "the subject supposed to know", who over-determines the nation as the zero-degree institution. "In fact, in that ability of authority to cancel the effects of institutional contradictions without cancelling their structural causes lies the structural condition of the relations of domination." 12

\section{Songs about Tito as a Mechanism of Producing a National "Subject Supposed to Know"}

The function of Tito in the ideological mechanisms of domination in the SFRY was precisely to over-determine the position of the national subject supposed to know. Tito occupied the position of the father of the nation and thus over-determined the institution of the Yugoslav nation. The narrative of Tito as the leader of the National Liberation Struggle thus functioned as an originary phantasm, the constitutive, fundamental fantasy that established the effect of the

\footnotetext{
${ }^{11}$ Ibid., 147.

${ }^{12}$ Rastko Močnik, “O naciji”, in Tri Teorije: Ideologija, nacija, institucija, 150.
} 
Pantic, R.: “The hero's voice let us follow, may Tito lead us"...

new state. Therefore, the function of songs about Tito was precisely to lend form to the mechanisms of the subjection of individuals, which provided the basis for a mobilizing national narrative and its teleology. Since the earliest days of the National Liberation Struggle, songs about Tito had been subjected to the function of producing this ideological effect of identification. The second meeting of the Antifascist Council for the National Liberation of Yugoslavia, held in Jajce, saw the first ever performance of the song "Uz Maršala Tita" (With Marshal Tito) composed by Oskar Danon, to lyrics by Vladimir Nazor. This piece sealed a pact between Tito as the military leader and marshal of the new Yugoslavia and the Yugoslav people. Danon's piece thus established a place of collective utterance, relying on the canons of the mass song in the spirit of socialist realism, featuring a steady and regular melody, marching rhythms, and a solemn character. The song's collectivist spirit rests on the tonal, melodic, and rhythmic correspondence between the music and the lyrics, performed by a mixed choir. The absence of vocal soloists and the song's firm formal logic thus generates the effect of collectivity, resolve, and uniformity that suited this revolutionary constitutive historical moment of creating a new social community. ${ }^{13}$

While the song's musical elements provide a rhythmic-melodic, semantically "empty" base for the interpellation effect, the song's lyrics over-determine this formal mechanism with concrete contents. Vladimir Nazor's verses thus established a particular and basic constitutive national narrative:

Uz maršala Tita, junačkoga sina, nas neće ni pakao smest'.

Mi dižemo čelo i kročimo smjelo i čvrsto stiskamo pest.

Rod prastari svi smo, al' Goti mi nismo, Slavenstva smo drevnoga čest.

Ko drukčije kaže, kleveće i laže, našu će osjetit' pest.

Sve prste na ruci u jadu i muci partizanska spojila je svijest.

Pa sad kad i treba, do sunca do neba visoko mi dižemo pest.
With Marshall Tito, the heroic son, not even hell shall stop us.

We raise our foreheads, we tread boldly, and clench our fists hard.

Of ancient kindred we are, but Goths we are not; part of the ancient Slavdom we are.

Whoever says otherwise, slanders and lies, and our fist shall feel.

The fingers on our hands, through misery and suffering, partisan awareness has joined together.

And now when there's need, to the sun, to the sky, we raise our fists high.

The opening verse establishes an inherently inclusive relationship of individuals gathered around the leader, Marshal Tito. Marshal Tito makes the interpellative call, to which members of the community answer ("we raise our

\footnotetext{
${ }^{13}$ For more on Yugoslav mass songs, see Vesna Mikić, "Mass Song as a Key Product of Yugoslav Music Propaganda", in: Massimiliano Sala (ed.), Music and Propaganda in the Short Twentieth Century, Turnhout, Belgium, Brepols Publishers, 2014, 159-165.
} 
foreheads") and which stimulates their practice ("we tread boldly and clench our fists hard"). The second verse defines the nation as an externally exclusive community, by evoking its autochthonous ethnic roots and the threat posed by another ethnic group ("Of ancient kindred we are, but Goths we are not"). The nation is thus defined here by its opposition to the enemy, with "Goths" referring to the German occupiers, as well as to the claims of the collaborationist Independent State of Croatia that the Croats were a Gothic rather than a Slavic nation. The second part of the verse expresses a strong resolve to fight the enemy, who threatens to jeopardize the existence of the Slavic nation ("Whoever says otherwise, slanders and lies, and our fist shall feel"). The third verse expresses the nation's strength, unity, and resolve to fight for itself as a community, asserting the power of the collective and ascribing to it supernatural, mythical power ("And now, when there's need, to the sun, to the sky, we raise our fists high"). In other mass songs about Tito from the time of the National Liberation Struggle and the early period of the new, socialist Yugoslavia, Tito's central place, as the nation's father and military leader, was even more prominently asserted. ${ }^{14}$ The lyrics of the song "Heroj Tito" (Hero Tito) written by Budimir Gajić and set to music by Josip Slavenski, boil down to a simple, mobilizing teleological narrative: the hero Tito leads his unified people to freedom, while the chorus in "Tito nek vodi nas" (May Tito Lead Us) by Angel Šurev and Milan Saks explicitly points to the song's interpellative function: "Sledimo heroja glas, Tito nek vodi nas" (Let us follow the hero's voice, may Tito lead us).

Therefore, these early songs about Tito reassert the myth of the National Liberal Struggle as a constitutive narrative of the new Yugoslavia. In them, Tito's authority as "the subject supposed to know" is based on Tito's military charisma, heroism, and leadership qualities. The phantasms whereby the figure of Tito interpellated individuals were therefore those of a brave, potent father who leads his people to liberation, but also requires his followers to make a sacrifice. Hence the potent mobilizing, revolutionary, and fighting potential of these songs, which answered the demands of an uncompromising fight against the occupiers, as well as the post-war cult of sacrifice in the youth work drives

\footnotetext{
14 Alongside mass songs originally composed by formally trained composers, most songs about Tito from this time were folk songs that emerged during the National Liberation Struggle. Most of them were contrafacta of already existing traditional songs. After the war, many of them were artistically reworked by formally trained composers and professional performers. The most prominent examples include "Druže Tito mi ti se kunemo" (Comrade Tito, Here's Our Pledge to You), "Ide Tito preko Romanije" (Tito Crossed Mount Romanija), "Sa Ovčara i Kablara" (From Ovčar and Kablar), "Druže Tito, ljubičice bijela" (Comrade Tito, Our White Violet), etc.
} 
Pantić, R.: “The hero's voice let us follow, may Tito lead us”...

to reconstruct and build the country anew. However, what characterizes mass songs about Tito from this period, as well as later songs, is the absence of a more explicit invoking of socialist ideology and its teleological communist narrative. Thus we may explain these songs by reference to Fredric Jameson's concept of libidinal apparatus. According to Jameson, libidinal apparatus constitutes a narrative "objectified fantasy-structure", 15 "an empty form or structural matrix", ${ }^{16}$ which may be reinvested and over-determined with various ideological contents. Jameson's concept of libidinal apparatus thus bears similarities with Močnik's conceptualization of the mechanisms of interpellative subjection, which provides individuals with a locus of collective utterance, binding them to the instance of "the subject supposed to know". These early mass songs about Tito thus secured an empty formal structure, libidinal apparatus, which was prerequisite for producing the effect of a new community.

Precisely this empty phantasmatic matrix may explain their longevity. Although mass songs about Tito were made in the spirit of the aesthetic of socialist realism that was abandoned and critiqued following Tito's falling out with Stalin, these songs were performed throughout the subsequent history of socialist Yugoslavia, at Party anniversaries, national holidays, and various state ceremonies. Their character of a libidinal apparatus ensures that they may be overdetermined to various ideological needs and practical applications. However, the change of Yugoslavia's Party, state, political, and economic-ideological course following the conflict with Stalin caused the production of songs about Tito to assume different aesthetic-ideological forms.

\section{The Function of Tito and Songs about Him in the Mechanisms of Domination in Yugoslavia's Self-management Socialism}

Following the Resolution of the Cominform and Tito's break with Stalin, Yugoslavia performed a U-turn in its foreign policy, relying on the United States and West European capitalist countries and their financial, political, and military assistance. This about-turn to the West and wholesale change of the politicalideological-economic framework of the state caused a series of structural social contradictions. In economic terms, Yugoslavia had to relinquish the Soviet statist economic system, which entrusted the entire management of the economic sector, as well as managing the surplus value of labour to the Party bureaucracy and its economic planning. The early 1950s thus saw the implementation of reforms

${ }^{15}$ Fredric Jameson, Fables of Aggression: Wyndham Lewis, the Modernist as Fascist, London/New York, Verso, 2008, 11.

${ }^{16}$ Ibid., 95. 
dubbed the three Ds: decentralization, de-bureaucratization, and democratization. In economic terms, decentralization meant granting autonomy to individual companies, that is, the autonomization of individual units of capital and their independence from state capital as a whole, which was previously controlled by the Party elite, which meant a partial return of the market-based economy, which, in turn, soon began to collide with the interests of the Party bureaucracy. To remain in power, the Party bureaucracy began a "contradictory process of its own expropriation in the struggle for its own survival". ${ }^{17}$ State property was thus rebranded as social property, the property of the working people who were purportedly in charge of it, which was presented by the bureaucracy as real democracy, in contrast to the formal democracy of the capitalist system. The Yugoslav "third way" in the guise of workers' self-management was thus presented as the peculiarity of the country that was allegedly the only one that relied upon Marxist-Leninist orthodoxy. However, instead of ushering in genuine workers' self-management, these reforms only bolstered a new technocratic, managerial class, which during the 1960 s openly clashed with the Party bureaucracy over the right to control the surplus value of work. In this way, the process of workers' self-management actually depoliticized the working class and politically emancipated the technocratic class. The ideology of self-management was therefore based on negating the class antagonism that existed, on the one hand, between the working class, as the subordinate class in the system, and, on the other hand, the Party bureaucracy and technocracy, as a faction of the ruling class. Regarding these contradictions, Tito's function was to reconcile the interests of the Party bureaucracy and technocracy, without which the bureaucracy itself could not keep the system functioning, but whose independence would spell the end of the Party itself and, at the same time, to secure the consensus of the working class, in whose name, on behalf of its interests, through the connection forged in the National Liberation Struggle, Tito legitimized his power. Tito thus presented himself as the representative of the working class, on whose behalf he pursued agreements with the two factions of the ruling class. In terms of the organization of the state, decentralization meant an ever growing "federalization of the federation" and granting ever more autonomy to the constituent republics. During the 1960s, the processes of economic and political decentralization gained further momentum and early in the ensuing decade brought the very existence of the shared state into a crisis.

Following Močnik's theory of domination mechanisms, one may conclude that Tito ruled self-management Yugoslavia precisely thanks to these structural

${ }^{17}$ Igor Bavčar, Srečo Kirn, and Bojan Korsika, "Kapital i rad u SFRJ, (I), (II), (III)", Naše teme: časopis mladih o društvenim zbivanjima, 1985, 1-3, 4-6, 10-12, 904. 
Pantić, R.: “The hero's voice let us follow, may Tito lead us”...

contradictions at its very foundations. In terms of nation-building, the concept of constructing a Yugoslav nation was critiqued and rejected as a remnant of the prewar ideology of integral Yugoslavdom. However, in parallel with this rejection of "unitary Yugoslavdom", it was precisely Tito's own cult that produced the effect of a unified society. Tito thus embodied a deferred Yugoslavdom, which enabled Yugoslav society to function as a whole, by acquiring a common position of utterance and a common mirror image. In ideological-economic terms, there were visible contradictions between the manifest official ideology of self-management socialism, which had to maintain the illusion that Yugoslav society was still pursuing the path of permanent revolution toward the abolition of the state and the introduction of free communal association, and the real levers of power and governance, which were distributed between two classes, the Party bureaucracy and the managerial technocracy. Therefore, in order to survive, Tito and the Party had to face their subjects with contradictory demands. On the one hand, they encouraged a market economy and the autonomization of the republics, whilst launching, on the other hand, frequent witch hunts against techno-liberalism and nationalism. This swaying between Party statism and market economy was the only way to reproduce the state community and its class structure, and Tito's ruling effect profited precisely from these structural contradictions of socialist Yugoslavia. Tito was thus able to remove the effects of these institutional contradictions, without removing their structural causes, and thereby to perform his rule as the instance of "the subject supposed to know". Yugoslavia's great institutional crises of the late 1960s and early 1970s were solved precisely by Tito's rule of fiat. In the first case, Tito sided with the technocratic faction and replaced the federal minister of the interior and most prominent advocate of a unitary Yugoslavia, Aleksandar Ranković, thereby stimulating a market economy and the autonomization of the republics. However, the same faction that Tito supported during the late 1960s was sacked in the early 1970s, accused of nationalism, in the case of the Croatian Party leadership, and of anarcho-liberalism, in case of their Serbian counterparts. The unstable course of the Party thus filled its subjects with anxiety and confronted them with contradictory demands, which meant that at times of great structural crises, decision-making was deferred to Tito's authority, whose role was to speak on behalf of the working people, who nominally ruled the state.

In line with these changes, identification mechanisms in self-management socialism had to become more flexible and decentralized. In Edvard Kardelj's words, one had to allow different flowers to blossom, provided they remained confined in the garden of socialism. ${ }^{18}$ Following the introduction of workers'

\footnotetext{
${ }^{18}$ See Predrag J. Marković, Beograd između Istoka i Zapada, Belgrade, Službeni list SRJ,
} 
self-management and the triple-D reforms, songs about Tito, as well as the construction of his identity image in other media in general, ${ }^{19}$ underwent significant changes. During the 1950s, Tito's image was thus de-militarized and Tito increasingly appeared in public, wearing civilian clothes. During the 1960s, he built his charisma primarily with his role in the Nonaligned Movement, where he promoted pacifism, the peaceful coexistence of the two blocs, a critique of nuclear weapons, the protection of small and undeveloped states and their right to pursue autonomous development.

Tito's merits in statesmanship were thus allowed to eclipse his military charisma, so at this time, Marshal Tito was pushed back by Comrade Tito. Tito's humanity, accessibility, pacifism, and goodness were thus asserted as that which distinguished him from Stalin; this was the basic component of the ideology of humanizing his cult, synchronized with the official turn toward "Marxism with a human face".

In line with this turning away from a Stalinist personality cult, the $1950 \mathrm{~s}$ and '60s saw no major production of songs about Tito. Their production was revived during the 1970s, when structural crises in the Yugoslav state called for a renewal and revitalization of Tito's cult and this trend went on into the 1980s, after Tito's death. However, the pattern of these new songs was significantly different from that of earlier mass songs. These changes in the formal pattern of songs about Tito may be viewed as manifestations of changes in ideological identification mechanisms themselves, whereby the Yugoslav social community reproduced itself. The wartime and immediately subsequent period in the history of the Yugoslav state featured a revolutionary momentum, whereby the new social community acquired its identity through a clear polarization against its external enemies (the occupiers, capitalist countries, later also the Soviet Union) and internal enemies (the bourgeoisie, the kulaks, reactionaries, traitors), who had to be destroyed for the community to survive and reach its goal (a classless communist society). The complex position of self-management Yugoslavia regarding the economy, politics, and relations with other states, entailed a proliferation of different identity images and semantic conceptual schemes (class, national, generational, sub-cultural, etc.), which jeopardized, as we saw above, the very existence and reproduction of the effect of society as a whole. In formal terms, one may note that these later songs about Tito are no longer choral piec-

1996, 333.

${ }^{19}$ For more on changes of Josip Broz Tito's identity in various media, see my article "Političko nesvesno identiteta Josipa Broza Tita u likovnim umetnostima, muzici, medijima i javnim priredbama", in: Istorija umetnosti u Srbiji XX vek: Realizmi i modernizmi oko hladnog rata, Belgrade, Orion art, 2012, 241-252. 
Pantic, R.: “The hero's voice let us follow, may Tito lead us"...

es, but songs performed by Yugoslavia's leading popular vocal soloists, modelled and styled after western pop music. Certain motives were retained from mass songs, such as fanfare-like beginnings, elements of marching music, choral background vocals, etc. However, these elements were incorporated into the context of popular music, dominated by drums, guitars, synthesizers, the piano, and brass sections derived from jazz bands. ${ }^{20}$ This time, the focus was not on the collectivist character of mass songs, which stemmed from the correspondence between rigorous formal composition and the lyrics performed by a choir, but on the expression of the performing capabilities of the soloists, who included the top stars of Yugoslav pop music at the time. The most popular songs in this new pop-cycle of songs about Tito were performed by Zdravko Čolić ("Druže Tito, mi ti se kunemo"), Đorđe Balašević ("Računajte na nas" - Count on Us, "Triput sam video Tita" - I Saw Tito Three Times), Oliver Dragojević ("Zagorje zdravo" - Hello, Zagorje), Jadranka Stojaković ("Srce mog naroda” - My People’s Heart), Meri Cetinić ("Poziv na borbu" - Call to Fight), the band Suncokreti ("Reč Titova" - Tito's Word), etc. One may view the emergence of pop music in Yugoslavia as a reflection of the country's westernization from the 1950s onwards, which, in the context of a partial and controlled market economy, brought a tidal wave of Western consumerist society that ushered in liberal individualism as an identification matrix, especially regarding Yugoslavia's youth. Therefore, the ideological objective of these songs may be understood as an attempt to reconcile Western liberalist individualism, brought by Yugoslavia's opening up to the West, with the collectivist character of socialist society. The chorus of Đorđe Balašević's song "Računajte na nas" thus seems paradigmatic of this song cycle as a whole:

Sumnjaju neki da nosi nas pogrešan tok, Jer slušamo ploče i sviramo rok, Al' negde u nama je bitaka plam, Kažem jer dobro znam: Računajte na nas.
Some suspect we're headed in the wrong direction, For we listen to records and play rock'n'roll, But the flame of the battles is in us, I tell you because I know: Count on us.

Together with Youth Day celebrations,${ }^{21}$ the function of these songs was to seal the pact between, on the one hand, Tito and the ethic of making sacrifices for the nation, grounded in the National Liberation Struggle, and, on the other

\footnotetext{
${ }^{20}$ See Vesna Mikić, “Tito marches...- Producing, Establishing and Reflecting Personality in/ through Music", in: Laila Ozolina and Imants Mežaraups (eds.), The $20^{\text {th }}$ Century and the Phenomenon of Personality in Music, Riga, Latvian Composers Union 2006, 2007, 163-169.

${ }^{21}$ For more on Youth Day celebrations, see Vesna Mikić, "Muzika kao sredstvo konstrukcije i rekonstrukcije revolucionarnog mita: Dan mladosti u SFRJ", Zbornik Matice srpske za scensku umetnost i muziku, 2009, 40, 129-136.
} 
hand, the new generation, nourished by Western popular culture and the individualist life ethic. This was meant to affirm that the West-leaning tendencies in the lifestyle of Yugoslavia's youth and the new identity images were not contradictory to the projected communist direction of the country's development, which still honoured the constitutive narrative of socialist Yugoslavia and stood ready to invest its own life in it. ${ }^{22}$ The function of this song cycle was therefore to renew the interpellative effect by affirming Tito's position as "the subject supposed to know".

With the collapse of socialist Yugoslavia, Tito ceased to perform this function. The late 1980s and 1990s were marked by a sweeping wave of nationalist hatred of Tito's work and personality, denounced by the new national leaders and ruling political and cultural elites in all of Yugoslavia's successor states as a totalitarian dictator and agent of rival ethnicities. However, since 2000, Yugoslavia's successor states have experienced the phenomenon of Titostalgia ${ }^{23}$ accompanied by a revival of the reception of songs about Tito. This phenomenon may be understood as an effect of disenchantment with ethno-nationalism and the promises made by the restoration of capitalism. Tito's Yugoslav era began to be seen as a golden age, a time of peace, prosperity, as well as a certain naivety and immaturity. Therefore, songs about Tito no longer produce an interpellating effect, nor do they directly participate in the process of social and class reproduction. Instead, they enable a conditional identification with "the subject supposed to believe", a phantasmatic citizen of socialist Yugoslavia, who enjoyed its prosperity, blissfully ensconced in his naïve beliefs. From their former position of a hegemonic ideological form endowed with the function of organizing the processes of social reproduction, songs about Tito have thus slid to the position of an imaginary identification of a nostalgic conditional belief and thereby become prey to the postmodern market of nostalgia.

\footnotetext{
${ }^{22}$ In "Reč Titova", the chorus features the following lines: "Narodi koji takvu imaju omladinu, za svoju budućnost ne treba da brinu" (Nations who have such a youth should worry not about their future).
}

${ }^{23}$ Mitja Velikonja, Titostalgija, Belgrade, Biblioteka XX vek, 2010, 151-173. 